\title{
Efficient Financing, Banking, and Foreign Exchange Operations in Mitigating Refined Petroleum Shortages In Nigerian Downstream Petroleum Supply Industry
}

By Dr. Itsekor Lucky Ubini

Walden University

Abstract- Every enterprise in Nigeria depends on refined petroleum product for either transportation, power, or heat source. The recurrent shortages or scarcity of petroleum products in Nigeria cripples business activities, which undermines the development of the economy. The purpose of this multiple case study was to identify the strategic role of finance, banks, and foreign exchange in mitigating petroleum shortages in the petroleum supply chain and to sustain business development in Nigeria. The study participants include ten senior leaders from two private-sector Nigerian downstream petroleum supply companies located in the Niger Delta region, who had successfully implemented strategies for petroleum supply. The resource based view theory served as the conceptual framework for the study. Data were collected through semi structured face-to-face interviews and review of operational and policy documents from the supply or marketing companies.

Keywords: refined petroleum, shortages, foreign exchange, banking, financing, economic development, downstream supply, marketing, supply chain.

GJMBR-C Classification: JEL Code: F65, E59

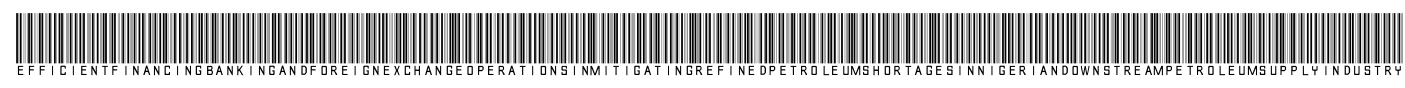

Strictly as per the compliance and regulations of:

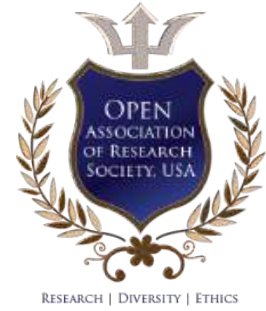

(c) 2019. Dr. Itsekor Lucky Ubini. This is a research/review paper, distributed under the terms of the Creative Commons Attribution-Noncommercial 3.0 Unported License http://creativecommons.org/licenses/by-nc/3.0/), permitting all non-commercial use, distribution, and reproduction in any medium, provided the original work is properly cited. 


\title{
Efficient Financing, Banking, and Foreign Exchange Operations in Mitigating Refined Petroleum Shortages in Nigerian Downstream Petroleum Supply Industry
}

\author{
Dr. Itsekor Lucky Ubini
}

Abstract- Every enterprise in Nigeria depends on refined petroleum product for either transportation, power, or heat source. The recurrent shortages or scarcity of petroleum products in Nigeria cripples business activities, which undermines the development of the economy. The purpose of this multiple case study was to identify the strategic role of finance, banks, and foreign exchange in mitigating petroleum shortages in the petroleum supply chain and to sustain business development in Nigeria. The study participants include ten senior leaders from two private-sector Nigerian downstream petroleum supply companies located in the Niger Delta region, who had successfully implemented strategies for petroleum supply. The resource based view theory served as the conceptual framework for the study. Data were collected through semi structured face-to-face interviews and review of operational and policy documents from the supply or marketing companies. Data were transcribed, analyzed, and validated through member checking and triangulation. The findings indicate that petroleum leaders must engage with efficient banks to obtain loans or letter of credit, liquidate letter of credit on time, obtain foreign exchange at best rates, and avoid documentation hitches and delays on international transactions. Findings may be used by petroleum business leaders and investors to create effective and efficient financial resource management strategies in the supply chain, leading to product availability, sustainability, poverty reduction, and economic development.

Keywords: refined petroleum, shortages, foreign exchange, banking, financing, economic development, downstream supply, marketing, supply chain.

\section{InTRODUCTION}

N igeria is a leading member of the organization of petroleum exporting countries (OPEC), with large reserves of oil. Irrespective of the availability of petroleum resources, shortages of refined petroleum products exist in Nigeria since the 1980s (Chigbu, Ubah, \& Chigbu, 2016; Osuala, 2013). The Nigerian National Petroleum Corporation (NNPC) regulates petroleum supply activities in the Nigerian downstream subsector (Osuala, 2013). However, the regulatory activities of the NNPC have not created an efficient and effective petroleum supply framework for the Nigerian nation (Adelabu, 2012; Ambituuni, Amezaga, \& Emeseh, 2014;

Author: Doctor of Business Administration (DBA), Walden University, Minneapolis, USA. e-mail: dr.litsekor@gmail.com
Osuala, 2013). Shortages in refined petroleum product supply exist in Nigeria, crippling business activities (Abutu, 2014; Aminu \& Olawore, 2014).

The oil and gas downstream sector was deregulated in 2003, to usher in private investors for a sustainable petroleum supply framework to enhance business development in Nigeria (Adelabu, 2012; Akinwotu, 2014; Osuala, 2013). In collaboration with the NNPC, activities of the private sector investors have grown to include depot ownership with supply chain activities such as petroleum importation, bulk storage, haulage or distribution, and bulk or retail outlet sales (Osuala, 2013). The support activities of the depot petroleum supply chain include administration, technology, human resources, marketing, security, finance, and accounting. The financing aspect of the industry usually involves banking and foreign exchange operations.

Finance is a key resource in the Nigerian Downstream Petroleum Supply Industry (NDPSI) as noted by Olukoju(2014). In the NDPSI, finance is scarce. Financing activities in the petroleum industry is a function of the Nigerian federal government until inefficiency sets into the sector (Chigbu et al., 2016). According to Menicucci and Paolucci(2016), the banking sector plays a significant role in the development of any country through financial intermediation such as the offering of credits and distribution of funds. Business in the NDPSI is based and dependent on U.S. foreign exchange dollars. Also, Menicucci and Paolucci (2016) noted that only sound banks can effect economic growth in a country.

The purpose of this article is to identify the strategic role of finance, banks, and foreign exchange operations in the petroleum supply chain to mitigate petroleum supply shortages and enhance business development in Nigeria. Findings from this study may provide petroleum organizational leaders with sustainable supply chain management (SCM) strategies regarding the contribution of improved financing, banking and foreign exchange operations for increased business development, increased revenue, job creation, and enhanced economic growth. 


\section{Conceptual Framework}

The resource based view theory (RBV) was used as the conceptual framework for this research. Barney (1991) postulated that to achieve sustainable competitive advantage, leaders of a firm must acquire resources (a) for creating effective and efficient strategies, (b) uncommon in the industry, (c) that are imperfectly imitable, and (d) non substitutable in the industry. The resources include financial, human, physical, technological, organizational, and reputational. Leaders can apply RBV to optimize resources to create value, leading to organizational effectiveness and efficiency (Barney, 1991; Crook \& Esper, 2014; Zimmermann \& Foerstl, 2014). Futhermore, Barney (2012) affirmed that creating competitive advantage automatically generates value for a firm.

Resource and capability management in the areas of finance, affect the NDPSI (Adelabu, 2012; Aminu \& Olawore, 2014). In the NDPSI, misappropriation of financial resource result in several inefficiencies such as (a) low refining output, (b) moribund refineries, (c) inadequate storage and pipeline infrastructures, (d) poor petroleum transport channels, (e) personnel shortages, and (f) irregular retail outlet activities (Adelabu, 2012; Aminu \& Olawore, 2014; Osuala, 2013).Financial resource and management inefficiencies contribute to refined product shortages, which negatively affect transportation and power, crippling business activities in Nigeria (Adelabu, 2012; Aminu \& Olawore, 2014; Itsekor, 2018, Osuala, 2013).

\section{a) A Review of the Professional and Academic Literature}

Financial resources in the Nigerian Downstream Petroleum Industry. Finance is a key resource in the NDPSI (Olukoju, 2014). The oil and gas industry is the main source of finance for activities in the Nigerian economy. Financing activities in the petroleum industry is a function of the Nigerian federal government until inefficiency sets into the sector (Chigbu et al., 2016). The Nigerian economy is structurally defective as the economy depends solely on the oil and gas sector for revenue (Olukoju, 2014).

Financing developmental activities for petroleum supply initiatives in Nigeria is negatively affected by oil theft activities in the Niger Delta region (Wilson, 2014). Wilson noted the effect of oil theft as (a) a fall in revenue to the Nigerian state, (b) a loss of human and natural resources, (c) an increase in state insecurity, and (d) poor financing of developmental projects in the petroleum industry. The consequence of oil theft is lack of crude supplies to the refineries and underdevelopment of the Nigerian business economy (Chigbu et al., 2016).

According to Alaba and Agbalajobi (2014), a limited inflow of investment occurs in the downstream sector because of low margin, uncompetitive pricing structure, and poor incentive mechanisms. The low level of investment has resulted in the limited development of the NDPSI, which inhibits business development in Nigeria (Monday, 2015). Moreover, improving the Nigerian economy will necessitate proper financing of the petroleum sector, which will require development and liberalization of the petroleum sector (Adelabu, 2012). Furthermore, Okwanya et al. (2015) posited that oil leaders should focus on market-oriented policies in the downstream sector. Market-oriented policies will make energy accessible to investors and consumers, which will increase shareholders incentive and encourage more investors into the sector (Okwanya et al., 2015).

Deregulation and privatization will free the Nigerian government from financing extensive projects, encourage private sector investments, and bring efficiency and effectiveness in resources management of the NDPSI (Chigbu et al., 2016). Moreover, Adelabu (2012) noted that deregulation and privatization would enhance effective utilization of resources, promote competition, and provide the necessary fund for the development of the sector. The deregulation of the NDPSI has a strong relationship to the economic development of Nigeria (Chigbu et al., 2016). However, deregulation and privatization will not succeed in a country that imports petroleum products with nonfunctional refineries (Adelabu, 2012). The deregulation of the NDPSI is to ensure a constant supply of products, reduce the price, enact competition, free up funds, and ensure efficiency in the supply of refined petroleum products (Chigbu et al., 2016).

Nigeria has earned huge petroleum dollars from the sales of petroleum products (Chigbu et al., 2016). Petroleum sales are subject to price volatility depending on international economic forces (Alimi \& Fatukasi, 2014). Okwanya (2015) noted that the change in oil price has no impact on GDP, consumer-purchasing index, money supply, but on the exchange rate of the U.S. dollar. The exchange rate of the U.S. dollar affects petroleum importation and hence supplies to Nigeria (Akinwotu, 2014; Alimi \& Fatukasi, 2014).

Nigerian Petroleum Industry. In 1956, oil was discovered in commercial quantities at Oloibiri in the Niger Delta region of Nigeria (Chigbu et al., 2016). The first oil international trade took place in 1958, and since then oil has become the backbone of the Nigerian economy (Aminu \& Olawore, 2014). Shell-D'Arcy was the foremost transnational oil company (IOC) that made the oil discovery (Osuala, 2013). The incoming years witnessed the participation of the Nigerian government in the affairs of petroleum management. In 1971, the federal government of Nigeria created the Nigerian National Oil Company (NNOC) to control and regulate oil-production activities that were dominated by IOCs 
(Osuala, 2013). Because of inefficiencies of the NNOC, the Nigerian National Petroleum Corporation (NNPC) was created in 1977 to replace the NNOC and affirm effective control over the petroleum industry (Osuala, 2013).

Nevertheless, the NNPC was not able to effectively and efficiently supervise of the Nigerian petroleum industry, as inefficiency still dominates the downstream sector (Adelabu, 2012; Osuala, 2013). Incompetence such as continual refined petroleum product shortages, dilapidated refineries and infrastructures, capacity underutilization of resources, and vandalism of petroleum industry equipment took over the Nigerian downstream industry (Aminu \& Olawore, 2014). However, in 2003, the federal government of Nigeria started the process of deregulation and liberalization of the downstream subsector to create supply efficiency, eradicate shortages, and enhance the economic development of the nation (Chigbu et al., 2016).

Refined Petroleum Production. All Nigerian four refineries have a total installed production capacity of 445,000 barrels per day (Alaba \& Agbalajobi 2014; Aminu \& Olawore, 2014). The refineries are: the Port Harcourt Refinery Company1and 2, the Warri Refinery and Petrochemical Company, and the Kaduna Refinery and Petrochemical Company (Akinwotu 2014; NNPC, 2016). The refineries process crude oil into different refined products such as petrol or premium motor spirit (PMS), diesel (AGO), dual purpose kerosene (DPK), lubricants, jellies, gas, and coal tar (Akinwotu, 2014; Oladepo, 2014). Aminu and Olawore (2014) noted that Nigeria's four refineries are not enough in relation to the country's population when matched to other members of oil-exporting nations.

Nigerian refineries are saddled with poor management of financial and material resources by petroleum business leaders, leading to low productivity (Alaba \& Agbalajobi, 2014; Osagibovo, 2012). Nigerian refineries produce less than $25 \%$ of the required 30 million liters of daily local demand (Alaba \& Agbalajobi, 2014). Oladepo (2014) emphasized that the undercapacity production has resulted from the dilapidated state of the refineries, lack of maintenance, negligence, and inappropriate resource utilization. Also, Aminu and Olawore (2014) noted that refined petroleum product shortages could be attributed to (a) low refining output of refineries, (b) inadequate pipeline infrastructures, (c) pipeline vandalism and rupture, and (d) inefficient road transportation of petroleum products. To improve the infrastructural facilities, the NNPC spent over 400 million dollars on maintenance of refineries between 1990 and 2000, without an increase in production (Adelabu, 2012; Chigbu et al., 2016). The low productivity of the existing refineries resulted in sourcing refined petroleum through importation from abroad (Alaba \& Agbalajobi, 2014).
Besides importation, Nigerian petroleum leaders and economic consultants proposed strategies to improve petroleum product production. Oladepo (2014) and Aminu and Olawore (2014) suggested that constructing more refineries will increase the nation's refining capacity and enhance petroleum availability. Aminu and Olayinka (2014) recommended the introduction of a petrol tax and removal of subsidies to reduce consumption and create availability. Chigbu et al. (2016) emphasized the judicious use of resources in the oil and gas sector to achieve sustainable development of the supply chain. Furthermore, Aminu and Olawore (2014) and Chigbu et al. (2016) recommended that privatizing existing refineries and pipeline networks would help create proper resource management to achieve fuel availability.

The federal government of Nigeria granted licenses to private investors to build refineries and depots to mitigate scarcity (Oladepo, 2014). The setting up of private sector participation by the Nigerian government was to increase production and distribution of refined petroleum products in addition to improve the economy (Chigbu et al., 2016; Oladepo, 2014). Private investors include independent oil marketers, major oil marketers, and private depot owners (Alaba \& Agbalajobi, 2014). Both local and international private investors and oil marketers have built depots across the country; nonetheless, they have not succeeded in establishing refineries (Alaba \& Agbalajobi, 2014).

Shortages of petroleum products. Petroleum shortages or scarcity is no news to the Nigerian economy. Since the 1980s, The Nigerian economy has experienced several eras of refined petroleum product shortages or scarcity (Adelabu, 2012; Aminu \& Olawore, 2014; Aminu \& Olayinka, 2014; Chigbu et al., 2016). Almost every business organization depends on refined petroleum product for either transportation or power generation (Chigbu et al., 2016). Refined petroleum product shortages have therefore resulted in underdevelopment and crippling of economic activities in Nigeria (Chigbu et al., 2016).

Government officials' neglect of infrastructures such as refineries and pipelines, and enhancing vandals and sabotage, affects the supply of refined products to the economy (Osuala, 2013). Oil spill and Pipeline vandalism disrupt both crude oil and refined products supply to refineries and consumer respectively (Anifowose et al., 2014). An oil spill in Nigeria occurs because of corrosion of pipes and storage tanks, operational error and oil tanker accidents (Anifowose et al., 2014; Osuala, 2013). In Nigeria, thieves break oil pipelines to siphon fuel, often with sparks results in an explosion, leading to hundreds of deaths of looters and bystanders (Anifowose et al., 2014). The resultant effect is refined petroleum product shortages and scarcity in the Nigerian economy. Furthermore, the NDPSI has 
cartels who determine prices, the volume of importation, and proportion of supply quantity to the market, while other marketers hoard products, resulting to supply shortages in the economy (Adelabu, 2012).

Business development. Nigeria operates an oilbased mono-product economy (Oriakhi \& lyoha, 2013). Oil is the mainstay of the Nigerian business economy (Chigbu et al., 2016). A continuous and sustainable supply of refined petroleum product will enhance business development and transform the Nigerian business landscape for productivity (Aminu \& Olawore, 2014). Petroleum shortages retard business development while product availability activates business development (Chigbu et al., 2016).

Petroleum products supply availability will lead to the development of business processes in Nigeria (Osuala, 2013). Electricity generation and supply have a negative effect on industrialization in Nigeria (Osobase \& Bakare, 2014). Aminu, Salau, and Pearce (2013) regretted that Nigerian business development is marred with poor power supply, a high cost of alternate power source among other weak infrastructures. Available and sustainable petroleum product activates energy source for large organizations, SMEs, and self-employed firms (Osobase \& Bakare, 2014). Existing companies recruit more staffers, business activities open-up while starters succeed because of the low cost of energy for production (Osobase \& Bakare, 2014).

Every sector in the Nigerian economy has a direct effect of petroleum shortage or scarcity since personnel, machinery, and money is affected (Chigbu et al., 2016). Cottage industries spring-up when petroleum product is available to substitute the unreliable national electricity supply. The net result is the development of business activities in Nigeria (Adelabu, 2012).

\section{ili. Research Method and Design}

Researchers use a qualitative method to understand and solve in-depth problems related to a phenomenon (Yin, 2014). I chose the qualitative method for this research. According to Harrison (2013), researchers use qualitative methods to explore human experience and meaning related to a phenomenon.

For this research, I used a case study design. Yin (2014) explained that a qualitative case study is a research process that incorporates an exploration of a problem within a context by using different data sources such as interviews, observations, and documents. The case study design was applicable to this study because I collected data from multiple sources of archival documents, interviews and existing works of literature.

\section{a) Study Population and Sample}

The population for the study was petroleum business leaders who work for private oil marketing companies (Depots) and who had successfully implemented strategies of petroleum supply in Nigerian downstream. I used purposeful sampling to select participants based on the study criteria. Purposeful sampling allows researchers to select participants who will provide the best responses to address a study problem (Smith, Colombi, \& Wirthlin, 2013). I interviewed 10 business petroleum leaders (Five each) from two organizations in the NDPSI (Company A and B) situated in Oghara, Delta state of Nigeria. According to Sharp et al. (2014), the number of participants for a case study ranges from 5 to 25 depending on the research requirement. I ensured data saturation by interviewing participants until no new themes emerged. Researchers achieve data saturation when participants produce the same information during the interview process and the researcher focuses on parameters and particular areas of the subject (O'Reilly \& Parker, 2013).

I focused on petroleum business leaders in the NDPSI. All Participants had supply experience and had the responsibility of (a) decision-making in sourcing of refined petroleum products within Nigeria and abroad, (b) storage of petroleum products, and (c) sales and marketing of petroleum products. O'Lynn and Krautscheid (2011) noted that selecting competent participants with an understanding of the research question is essential for the study.

\section{b) Data Collection}

I was the primary instrument for data collection in this study. Marbash (2013) noted that researchers are the primary instrument for data collection in qualitative studies. I collected data using semistructured interviews, with open-ended questions, in a face-to-face setting. Haahr et al. (2014) affirmed that researchers must recognize themselves as the major instrument when conducting research. Stuckey (2013) indicated that the semistructured interview process can provide a clear set of instructions for researchers along with dependable and comparable qualitative data. The semistructured open-ended data collection process provides researchers with options to collect data that are relevant to research problems (Bryman, 2012). Furthermore, Doody and Noonan (2013) noted that researchers use face-to-face interviews to generate information from participants to develop knowledge.

In addition to semistructured interviews, I reviewed archival operational and policy documents with interview responses from participants for methodological triangulation. With methodological triangulation, data from different sources are used to corroborate, illuminate and explore research questions (Marshall \& Rossman, 2016). Also, Wahyuni, (2012) affirmed that collating data from multiple sources allow researchers to have access to more information, check consistency and enhance the robustness of results. I employed member checking to enhance the reliability and validity of the data collection instrument and the research process. Participants received a copy of my 
interpretation of transcribed interview to ensure correct representation of responses.

\section{c) Data Analysis}

Marshall and Rossman (2016) stated that qualitative data analysis is a process whereby researchers search for patterns, themes, and relationships. I employed methodological triangulation process for the research analysis. Case study researchers use triangulation to test the validity of a study through the convergence of information from different sources (Carter et al., 2014).

I analyzed the interviews and archived documents using QSR NVivo ${ }^{\circledR}$, computer-assisted qualitative data analysis software (CAQDAS) tool. In qualitative studies, researchers utilize $\mathrm{NVivo}^{\circledR}$ for data collection, organization, and analysis of audio and textual data (QSR International, 2014). I interviewed business leaders in the two organizations to obtain patterns and themes that may lead to the provision of financial resource strategies for sustainable petroleum product supply in Nigeria. I assigned letters and numbers to each participant for anonymity purposes. The letter $L$ and a number represent petroleum business leaders (i.e., L1) in the companies A and B.

\section{Discussions And Findings}

The banking sector plays a significant role in the development of any country through financial intermediation such as the offering of credits and distribution of funds (Menicucci \& Paolucci, 2016). Banks facilitate economic growth by lending funds to creditors at an appropriate rate to optimize profit in business dealings (Tennant \& Tracy, 2014). According to Obamuyi (2013), the gains of the real sector of the Nigerian economy depend on how well banks play financial intermediary roles. Furthermore, Menicucci and Paolucci (2016) noted that only sound banks can effect economic growth in a country.

All participants affirmed that the NDPSI is capital intensive and requires a huge amount of financial resources to operate (Giwa-Osagie \& Ehigiato, 2015). Also, all participants agreed that the business is $100 \%$ dependent on the availability of the U.S. foreign exchange dollars (USD) and the operation of good banks. The exchange rate of the U.S. dollar affects petroleum importation and product availability in Nigeria (Akinwotu, 2014; Alimi \& Fatukasi, 2014; Oriakhi \& lyoha, 2013). According to Participant $L 4 A$, finance is scarce in the NDPSI, and most marketers acquire finance through a loan from banks.

Eighty percent of participants stated that the petroleum importation business is transacted with the aid of Nigerian banks. According to Participants L1A, $\mathrm{L} 2 \mathrm{~A}$, L8B, and L10B, banks are needed for (a) funding procurement of products, (b) having a memorandum of understanding with the international trading partner to agree on terms of payment, (c) issuance of letters of credit (LC), and (d) sourcing USD for marketers from the Central Bank of Nigeria (CBN) at good exchange rate. Participants L1A, L2A, L8B, and L10B noted that the availability of USD to business leaders for the importation of refined petroleum products depends on the regulatory role of $\mathrm{CBN}$ and other banks. The CBN performs the regulatory and supervisory role over all banks, including maintaining an effective monetary and financial system in Nigeria (Ajibo, 2015; Giwa-Osagie \& Ehigiato, 2015).

Alberto (2015) noted that banks are very important to society, and only banks with good standards can effect economic development. Business leaders need the backing of a good bank to support LC procurement to avoid hitches with the supplier or international traders (Giwa-Osagie \& Ehigiato, 2015). To create efficiency, marketers liquidate LC on time to avoid incurring more charges, as emphasized by Participants L1A, L6B, and L7B. Participant L1A further explained that Nigerian business leaders may not be able to buy on credit from abroad; therefore, they need the support of banks through letters of credit. Participants L1A and L2A emphasized that insurance companies cover transactions because of the risky nature of the business, including volatile and flammable properties of the products. According to Participants L1A and L2A, the cost of the petroleum product insurance increases the final landing cost of the product.

Adeniran, Yusuf, and Adeyemi (2014), Rajhans and Jain (2015) posited that the exchange rate is the value of one currency expressed in terms of some other currency. Obansa, Okorafor, Aluko, and Millicent (2013) noted that the exchange rate system is an important requisite in global business especially for developing countries embracing globalization concepts for economic development. Obansa et al. and Adeniran et al. affirmed that there is a positive relationship between the exchange rate and the economic development in Nigeria. Nigeria foreign exchange policies are characterized by inconsistencies, which affects business growth in the country (Adeniran et al., 2014). Adeniran et al. further noted that an increase in exchange rates leads to increases in imports, and reduced exports, while a decrease leads to a reduction in the importation and increases exports.

The business of purchasing petroleum products overseas is transacted in foreign exchange USD (Akinwotu, 2014). All participants affirmed that the availability of the U.S. dollar and the prevailing exchange rate of the currency affect products importation. Participants L3A, L5A, L9B, and L10B declared that if the exchange rate is high, marketers may not be able to import because of the high cost and product scarcity looms. If the exchange rate is low or favorable, petroleum product availability and sustainability is 
achieved. Participant L7B noted that different banks offer different foreign exchange rates, and business leaders go for best rates to enhance efficiency and profitability.

According to Participant L6B "marketers establish a credit line with reputable banks to guarantee the trader to supply the products. Interest is paid on the dollar. Companies sell products and liquidate back to L.C. The line of credit takes between 30 to 40 days for liquidation." Furthermore, Participant L6B noted that the deregulation of the dollar from \#199.00 (one hundred and ninety-nine naira) to \#306.00 (three hundred and six naira) negatively affected the supply industry; creating instant credits from marketers to banks. The naira (local Nigerian currency) devaluation negatively affected importation and hence the availability of petroleum products. Also, Participant L6B stated that because of the high cost of doing business and difficulty in accessing foreign exchange, not all marketers are importing petroleum products in Nigeria.

According to Participant L7B, petrol is an international product and there is a platform for petrol price in the international business. Ji, Geng, and Fan (2014) noted that the Western Texas Intermediary (WTI) platform is often employed in determining international petroleum prices. For optimal resources utilization, Participant L7B reiterated that business leaders lock the purchase price at a good rate to create efficiency.

Suliman, Elmawazini, and Shariff (2015) advised that governments should design policies to accommodate instability in the exchange rate system to attract both local and foreign investors. Participant L8B emphasized that marketers do not have easy access to foreign exchange because of unfavorable government policies (Giwa-Osagie \& Ehigiato, 2015). Government policies on dollar sourcing affect marketers (Obamuyi, 2013). According to Participant L8, the cost of a dollar in the black market is expensive, making several depot owners not to import products, leading to scarcity of products. However, participants L10B, L7B stated that organizations that are financially strong, do not rely on loans and government, instead invest company savings in procuring products, since charges on bank loans impart on landing cost or selling price of the product. Furthermore, Participant L8 lamented the capping of petroleum prices by the federal government, which discourages investment in the industry. Alaba and Agbalajobi (2014) posited that a limited inflow of investment occurs in the downstream sector because of low margin, uncompetitive pricing structure, and poor incentive mechanism. The low level of investment has resulted in the limited development of the NDPSI, which inhibits business development in Nigeria (Monday, 2015).

Participant L10B narrated that in the year 2016, the U.S. dollar was scarce and expensive and created product shortages across the country because of high importation cost. By intervention, the Nigerian federal government paid subsidy to importers and also paid 'Petroleum Equalization Fund (PEF). to transporters to ensure that the product was circulated through the country. In Nigeria, the government subsidizes refined petroleum products to the citizens (Abutu, 2014; Okwanya et al., 2015). The landing cost of the imported refined petroleum is higher than the local cost hence the federal government subsidizes the product to create a balance in the economy (Abutu, 2014). In Table 1, I present the frequency at which participants mentioned the significance of excellent banking and foreign exchange operations in NDPSI.

Table 1: Efficient Banking and Foreign Exchange Operations (Frequency)

\begin{tabular}{ccc}
\hline Participants & Interview questions & Total number of references \\
\hline L1A & $1,2,7$ & 11 \\
L2A & $1,3,8,10$ & 12 \\
L3A & $1,2,5,6,12$ & 8 \\
L4A & 2 & 2 \\
L5A & 2 & 6 \\
L6B & $1,2,6$ & 9 \\
L7B & $1,2,5,11,12$ & 10 \\
L8B & $1,2,5,6$ & 10 \\
L9B & 1,2 & 4 \\
L10B & 2 & 7 \\
\hline
\end{tabular}

\section{a) Archival Document Review}

Giwa-Osagie and Ehigiato (2015) affirmed that the NDPSI is capital intensive and requires a huge allocation of financial resources to operate efficiently. I reviewed the operational and policy statement documents of company's A and Company's B regarding content on banking and foreign exchange operations. The archival documents showed that leaders in both companies have a core strategy for improving operational funding cost, reducing the cost of sales, and driving down business manual cost, with the aid of strict financial backings. Banking operations include charging interest on funds and issuance of foreign exchange, impact profitability on international business (Ajibo, 2015; Giwa-Osagie \& Ehigiato, 2015). Giwa-Osagie and Ehigiato (2015) postulated that petroleum business leaders need the backing of good banks to secure funds for international business. 
Furthermore, Alberto (2015) posited that good banks are necessary organizations needed for societal and economic development.

\section{b) Application to Practice}

Menicucci and Paolucci (2016) affirmed that only good banks can affect profitability in business organizations. In the Nigerian petroleum industry, finance is scarce. Participants emphasized on the appropriate application of financial resources to each of the petroleum supply chain segments to facilitate efficiency. Since the private sector depends largely on importation, acquiring foreign exchange through bank becomes paramount; marketers can be successful only if foreign exchange is obtained at existing low rates. A high rate will transact to doing business at a high cost, which will impact the landing cost of the products. Participant L6B noted that most firms do not import because of the high cost of foreign exchange. Furthermore, marketers use loans in the form of an LC to purchase products from international traders (Giwa-Osagie \& Ehigiato, 2015). Petroleum business leaders or Marketers must transact business with banks at good interest rates to liquefy the LC and make profits. In Nigeria, banks finance oil and gas business through letters of credits, whose customers, in turn, pay interest to the banks (Giwa-Osagie \& Ehigiato, 2015).

\section{Recommendations and Conclusion}

Refined petroleum product shortages or scarcity have undermined the development of economic and business activities in Nigeria (Aminu \& Olawore, 2014; Osuala, 2013). The Nigerian government involvement of the private sector in the business of refined petroleum product supply is a way to improve petroleum supply (Chigbu et al., 2016). Based on the study findings, I recommend the following actions:

- Petroleum business leaders must engage with efficient banks to obtain loans or LC at good rates.

- Marketers should liquidate LC on time to avert further charges that will increase product landing cost.

- Firms with enough savings can invest in importation to avoid incurring charges from LC loans.

- Petroleum business leaders should obtain foreign exchange at the best rates.

- Petroleum business leader should transact international business with the right documentation, right timing, without problems and delays.

Implementation of these strategies by petroleum business leaders will mitigate petroleum shortages from the financial resource perspective as also affirmed by Itsekor (2018). The findings indicate that petroleum leaders should be involved in engaging efficient banks for LC, liquidate LC on time, obtain foreign exchange at best available rates, transact international business with right documentation, and avoid delays. Petroleum firms applying the appropriate financial strategy will enhance supply sustainability and improve economic development in Nigeria.

\section{References Références Referencias}

1. Abutu, O. P. (2014). Consequences of the January 2012 oil subsidy removal in Nigeria. Journal of Business and Retail Management Research, 8, 24-30. Retrieved from http://www.jbrmr.com

2. Adelabu, N. S. (2012). The political economy of oil deregulation in Nigeria's fourth republic: Prospects and challenges. Journal of Emerging Trends in Educational Research and Policy Studies, 3, 193-198. Retrieved from www.jeteraps.scholar linkresearch.org

3. Adeniran, J. O., Yusuf, S. A., \& Adeyemi, O. A. (2014). The impact of exchange rate fluctuation on the Nigerian economic growth: An empirical investigation. International Journal of Academic Research in Business and Social Sciences, 4, 224231. Retrieved from www. hrmars.com/index.php? page $=$ abt\%20ijarbss\&CAT $=1$

4. Ajibo, K. I. (2015). Risk-based regulation: The future of Nigerian banking industry. International Journal of Law and Management, 57, 1-21. doi:10.1108/IJLMA02-2014-0014

5. Akinwotu, S. A. (2014). A comparative study of the discursive strategies in the media interviews of participants in the January 2012 fuel subsidy removal crisis in Nigeria. Journal of Arts and Humanities, 3(7), 21-33. Retrieved from www.theartsjournal.org/index.php/site/issue/view/21

6. Alaba, O. C., \& Agbalajobi, S. A. (2014). Evaluation of private refineries and depots in distribution of petroleum products in Nigeria. International Journal of Engineering and Technology, 4, 118-126. Retrieved from www.psu.edu

7. Alberto, M. (2015). Professionalism in banking: The best root to recovery. Aestimatio, The International Journal of Finance, 10, 2-13. doi:10.5605/IEB.10.6

8. Alimi, R. S., \& Fatukasi, B. (2014). The role of oil prices and real exchange rate on the output growth in Nigeria. International Journal of Research Economic, 3, 70-79. Retrieved from www.researchgate.net/profile/R_Alimi/publication/26 5051311

9. Ambituuni, A., Amezaga, J., \& Emeseh, E. (2014). Analysis of safety and environmental regulations for downstream petroleum industry operations in Nigeria: Problems and prospects. Environmental Development, 9, 43-60. doi:10.1016/j.envdev. 2013.12.002

10. Aminu, S. A., \& Olawore, O. P. (2014). Empirical investigation of challenges of distribution of premium motor spirit (PMS) in federal capital 
territory (FCT), Abuja and environs, Nigeria. International Journal of Management Sciences and Humanities, 2(2), 11-38. Retrieved from www.ijmsh.com

11. Aminu, S. A., \& Olayinka, K. A. (2014). Achieving petrol conservation through higher pump price in Nigeria: Evidence from the transport sector of Lagos State. International Journal of Management Sciences and Humanities, 2(2), 102-122. Retrieved from www.jimsh.com

12. Aminu, S. A., Salau, T. J., \& Pearse, O. E. (2013). Attracting more foreign direct investment (FDIs) to alleviate poverty in Nigeria. International Journal of Management Sciences and Humanities, 1, 65-79. Retrieved from www.ijmsh.com

13. Anifowose, B., Lawler, D., Horst, D., \& Chapman, L. (2014). Evaluating interdiction of oil pipelines at river crossings using Environmental Impact Assessments. Area, 46(1), 4-17. doi:10.1111/area. 12065

14. Barney, J. (1991). Firm resources and sustained competitive advantage. Journal of Management, 17, 99-120. doi:10.1177/014920639101700108

15. Barney, J. B. (2012). Purchasing, supply chain management and sustained competitive advantage: The relevance of resource-based theory. Journal of Supply Chain Management, 48(2), 3-6. doi:10.1111/ j.1745-493X.2012.03265.X

16. Bryman, A. (2012). Social research methods (4th ed.). Oxford, UK: Oxford University Press.

17. Carter, N., Bryant-Lukosius, D., Dicenso, A., Blythe, J., \& Alan, J. (2014). The use of triangulation in qualitative research. Oncology Nursing Forum. 41, 545-547.doi:10.1188/14.ONF.545-547

18. Chigbu, U. S., Ubah, C. P., \& Chigbu, E. E. (2016). Deregulation of the petroleum downstream sector and Nigerian economy: An econometric investigation. International Journal of Business and Applied Social Science, 2 (9), 16-27. Retrieved from www.ijbassnet.com

19. Crook, T. R., \& Esper, T. L. (2014). Do resources aid in supply chain functioning and management? Yes, but more (and more precise) research is needed. Journal of Supply Chain Management, 50(3), 94-97. doi:10.1111/jscm.12055

20. Department of Petroleum Resources (2016). Operations. Retrieved from https://dpr.gov.ng/index

21. Giwa-Osagie, O., \& Ehigiato, E. (2015). Financing options in the oil and gas sector in Nigeria. Journal of Energy \& Natural Resources Law, 33(3), 218-240. doi.10.1080/02646811.2015.1043823

22. Haahr, A., Norlyk, A., \& Hall, E. O. (2014). Ethical challenges embedded in qualitative research interviews with close relatives. Nursing Ethics, 21, 615. doi:10.1177/0969733013486370

23. Harrison III, R. L. (2013). Using mixed methods designs in the journal of business research, 1990-
2010. Journal of Business Research, 66, 2153-2162. doi:10.1016/j.jbusres.2012.01.006

24. Itsekor, L. U. (2018). Mitigating petroleum product shortages in the Nigerian downstream petroleum supply industry. (Walden Dissertation and Doctoral Studies) https://ezp.waldenulibrary.org/login?url= https://search-proquestcom.ezp.waldenulibrary. org/docview/2033044375?accountid=14872. Also available atwww.scholarworks@waldenu.edu

25. Ji, Q., Geng, J. B., \& Fan, Y. (2014). Separated influence of crude oil prices on regional natural gas import prices. Energy Policy, 70, 96-105. doi.org/ 10.1016/j.enpol.2014.03.019

26. Marbach, E. (2013). Towards a phenomenological analysis of fictional intentionality and reference. International Journal of Philosophical Studies, 21, 428-447. doi:10.1080/09672559.2013.801631

27. Marshall, C., \& Rossman, G. (2016). Designing qualitative research (6th ed.). Thousand Oaks, CA: Sage.

28. Menicucci, E., \& Paolucci, G. (2016). The determinants of bank profitability: Empirical evidence from European banking sector. Journal of Financial Reporting and Accounting, 14(1), 86-115. doi 10.1108/JFRA-05-2015-0060

29. Monday, J. U. (2015). Local content policy, human capital development and sustainable business performance in the Nigerian oil and gas industry. Journal of Management and Sustainability, 5(1), 7583. doi:10.5539/jms.v5nlp75

30. Nigerian National Petroleum Corporation. (2016). Profile/products. Retrieved from www.nnpc group.com

31. Obamuyi, T. M. (2013). Determinants of banks' profitability in a developing economy: Evidence from Nigeria. Organizations and Markets in Emerging Economies, 4(2), 97-111. Available at www.ceeol.com

32. Obansa, S. A. J., Okoroafor, O. K. D., Aluko, O. O., \& Millicent, E. (2013). Perceived relationship between exchange rate, interest rate and economic growth in Nigeria: 1970- 2010. American Journal of Humanities and Social Sciences: 1, 116-124. doi.10.11634/232907811604374

33. Okwanya, I., Moses, O., \& Pristine, J. M. (2015). An Assessment of the impact of petroleum subsidy on consumer price index in Nigeria. Global Journal of Interdisciplinary Social Sciences, 4(1), 36-39. Retrieved from www.gifre.org

34. Oladepo, I. O. (2014). Evaluation of petroleum products marketing in a globalizing economy: Conceptual evidence from Nigeria. British Journal of Marketing Studies, 2 (2), 71-81. Retrieved from www.eajournals.org

35. Olukoju, A. (2014). The challenges of sustainable development in Nigeria. International Journal of 
Management Sciences and Humanities, 2(2), 1-10. Retrieved from www.ijmsh.com

36. O'Lynn, C., \& Krautscheid, L. (2011). Original Research: 'how should I touch you?': A qualitative study of attitudes on intimate touch in nursing care. American Journal of Nursing, 111, 24-31. doi:10.1097/10.1097/01.NAJ.0000395237.83851.79

37. O'Reilly, M., \& Parker, N. (2013). Unsatisfactory Saturation: A critical exploration of the notion of saturated sample sizes in qualitative research. Qualitative Research, 13, 190-197. doi:10.1177/ 1468794112446106

38. Oriakhi, D. E., \& lyoha, D. S. (2013). Oil price volatility and its consequence on the growth of the Nigerian economy: An Examination (1970-2010). Asian Economic and Financial Review, 3, 683-702. Retrieved from: http://aessweb.com/journaldetail. php?id $=5002$

39. Osobase, A. O. \& Bakare, A. T. (2014). The nexus between electricity generation, supply, and manufacturing sector performance in Nigeria (19752011). International Journal of Management Sciences and Humanities, 2(2), 123-139. Retrieved from www.ijmsh.com

40. Osuala, U. S. (2013). The sublimeness of sleaze in the NNPC in the fourth republic, 1999-2007: A historical conspectus. Journal of Culture, Society and Development, 2, 52-59. Retrieved from www.iiste.org/journals/index.php/JCSD

41. QSR International. (2014). NVivo 10. Retrieved from http://www.qsrinternational.com/

42. Rajhans, R. K., \& Jain, A. (2015). Volatility spillover in foreign exchange markets. Paradigm, 19, 137151. doi:10.1177/0971890715609846

43. Rowley, J. (2012). Conducting research interviews. Management Research Review, 35, 260-271. doi:10.1108/01409171211210154

44. Sharp, R., Grech, C., Fielder, A., Mikocka-Walus, A., Cummings, M., \& Esterman, A. (2014). The patient experience of a peripherally inserted central catheter (PICC): A qualitative descriptive study. Contemporary Nurse: A Journal for the Australian Nursing Profession, 48, 26-35. doi:10.5172/conu. 2014.48.1.26

45. Smith, R. A., Colombi, M. J., \& Wirthlin, R. W. (2013). Rapid development: A content analysis comparison of literature and purposive sampling rapid reaction projects. Procedia Computer Science, 16, 475-482. doi:10.1016/j.procs.2013.01.050

46. Stuckey, H. (2013). Three types of interviews: Qualitative research methods in social health. Journal of Social Health and Diabetes, 1(2), 56. doi:10.4103/2321-0656.115294

47. Suliman, A., Elmawazini, K., \& Shariff, M. Z. (2015). Exchange rates and foreign direct investment: Evidence for sub-Saharan Africa. The Journal of
Developing Areas, 49, 203-226. Retrieved from www.muse.jhu.edu

48. Wahyuni, D. (2012). The research design maze: Understanding paradigms, methods, and methodologies. Journal of Applied Management Accounting Research, 10, 69-80. Retrieved from http://cmawebline.org

49. Wilson, G. (2014). The Nigerian state and oil theft in the Niger Delta region of Nigeria. Journal of Sustainable Development in Africa, 16(1), 69-81. Retrieved from www.jsd-africa.com

50. Yin, R. (2014). Case study research method: Design and method (5th ed.). Thousand Oaks, CA: Sage.

51. Zimmermann, F., \& Foerstl, K. (2014). A meta-analysis of the "purchasing and supply management practice-performance Link". Journal of Supply Chain Management, 50(3), 37-54. doi: 10. 1111/jscm. 12051 